\title{
EDITORIAL
}

\section{Do patients with COPD benefit from treatment with inhaled corticosteroids?}

\author{
C.P. van Schayck*, P.M. van Grunsven, P.N.R. Dekhuijzen
}

In the past few years, treatment with inhaled corticosteroids has become increasingly important in asthma [1, 2]. It appears that inflammation of the airway wall is a major pathophysiological mechanism underlying asthma [3], and perhaps also chronic obstructive pulmonary disease (COPD) [4]. Some long-term studies in asthmatic patients over 1 and 2 yrs have shown that maintenance treatment with inhaled corticosteroids is beneficial [57]. In contrast to asthma, the efficacy and therefore the precise role of inhaled corticosteroids is less clear in the treatment of patients with COPD [8, 9]. Corticosteroids are generally given in COPD, in order to treat exacerbations, for a relatively short period of time. The efficacy of long-term treatment with inhaled steroids is not yet established. Whilst in asthma the response is rapid, there are indications that (some) patients with COPD may only respond adequately to (oral) corticosteroids after 6 months to 2 yrs of therapy [10]. We have, therefore, investigated the literature over the past $15 \mathrm{yrs}$ on short-term as well as long-term response to inhaled steroids in COPD. This was done by means of a Medline Search (MeSH headings and/or free text words: antiinflammatory-agents-steroidal; chronic airflow obstruction; COPD-chronic obstructive pulmonary disease). Only randomized controlled studies (English-written) with inhaled steroids were included. Special attention was paid to possible predictors of a long-term response to inhaled steroids in COPD.

\section{Effects of inhaled steroids in COPD}

Of the 103 studies found in Medline, only 14 matched the inclusion criteria. Most of these studies were shortterm studies, ranging from 2 weeks to 3 months [11-20]. Only a few long-term prospective studies with inhaled corticosteroids in COPD were available, ranging 12-30 months [21-24], of which one study [22] was the (24 month) follow-up of a 12 month study [21]. The other long-term study [23] did not make a distinction between asthma and COPD but studied post-hoc a group with a symptom-based diagnosis of COPD. There was one other study published in abstract form only, of long-term controlled use of inhaled steroids in COPD [25].

Table 1 presents an overview of the design and results of these studies. Most short-term studies show that inhaled steroids have beneficial effects on lung function (forced expiratory volume in one second (FEV1), forced vital

*Correspondence: C.P. van Schayck, Dept of General Practice, Nijmegen University, P.O. Box 9101, 6500 HB Nijmegen, The Netherlands. capacity (FVC) and peak expiratory flow rate (PEFR)) when given in dosages of 1,500-3,000 $\mu \mathrm{g}$ beclomethasone daily for 2-6 weeks [11-17]. When compared with oral steroids, the effects of inhaled steroids on lung function were less pronounced [11-15]. Lower dosages of budesonide $(800-1,600 \mu \mathrm{g})$ for 8 weeks to 3 months did not result in a significant improvement in lung function [18-20]. None of these studies showed any effect on bronchial hyperresponsiveness as assessed by the provocative concentration of agonist producing a $20 \%$ fall in FEV1 (PC20), although high doses of beclomethasone may have some effect on the inflammation assessed by means of bronchoalveolar lavage (BAL) [17]. Two studies showed small effects on one specific symptom (dyspnoea and cough) but not on symptom scores in general [18, 19].

Long-term studies with $800-1,600 \mu \mathrm{g}$ beclomethasone or budesonide for 12-30 months [21-25] generally showed the same tendency: small improvements in lung function (FEV1, FVC and PEFR), but no change in bronchial hyperresponsiveness (PC20). During inhaled steroid usage, symptoms decreased to a small extent [22, 24], and there was a small reduction in the number of exacerbations $[22,23]$ or the days of oral steroid use during exacerbations [25]. As could be expected, the treatment benefits of inhaled corticosteroids were much more pronounced in patients with asthma than in those with COPD [21-23]. In asthma, inhaled steroids not only markedly improved the level of lung function and bronchial hyperresponsiveness, but also the yearly decline in lung function (the progression of the disease) to a far greater extent than in COPD. For instance, in one study [22], the average increase in FEV1 during steroid therapy in COPD was $0.098 \mathrm{~L}$, which was only $43 \%$ of the $0.228 \mathrm{~L}$ increase in asthma. In the same study, the PC20 decreased by 3.2 doubling doses in COPD, whereas in patients with asthma an increase of 2.1 doubling doses was found during the same period $(\mathrm{p}<0.05)$.

\section{Predictors of a long-term response to inhaled steroids in COPD}

So far, there has only been one study investigating the predictors of a long-term response to inhaled steroids [23]. Within a group of 91 patients, treated with beclomethasone $800 \mu \mathrm{g}$ daily for 30 months, it was shown that subjects who did not smoke, who had allergies, or who were less than 40 yrs of age benefited more from their treatment (improvement in lung function) than did those who smoked, did not have allergies, or were over $40 \mathrm{yrs}$ of age. A further analysis of this study showed that the 
Table 1. - Summary of studies published so far concerning the effect of inhaled steroids in COPD

\begin{tabular}{|c|c|c|c|c|c|}
\hline [Ref.] & $\begin{array}{c}\text { Pts } \\
\mathrm{n}\end{array}$ & $\begin{array}{l}\text { Therapy } \\
\mu \mathrm{g} \cdot \text { day }^{-1}\end{array}$ & Design & Drop-outs & Results \\
\hline \multicolumn{6}{|c|}{ Short-term studies } \\
\hline [11] & 12 & $\begin{array}{l}\text { Beclomethasone } \\
1,600,2 \text { weeks }\end{array}$ & $\begin{array}{l}\text { Double-blind/"cross-over" } \\
\text { comparison }\end{array}$ & - & FEV $1 \uparrow$, but less than with prednisone \\
\hline [12] & 83 & $\begin{array}{l}\text { Beclomethasone } \\
1,500,2 \text { weeks }\end{array}$ & $\begin{array}{l}\text { Double-blind/"cross-over" } \\
\text { comparison }\end{array}$ & - & $\begin{array}{l}\text { FEV1, FVC and PEFR } \uparrow \text {, but less than with } \\
\text { prednisolone }\end{array}$ \\
\hline$[13,14]$ & 127 & $\begin{array}{l}\text { Beclomethasone } \\
1,500,2 \text { weeks }\end{array}$ & $\begin{array}{l}\text { Double-blind/"cross-over" } \\
\text { comparison }\end{array}$ & - & $\begin{array}{l}\text { FEV1, FVC and PEFR } \uparrow \text {, but less than with } \\
\text { prednisolone }\end{array}$ \\
\hline [15] & 107 & $\begin{array}{l}\text { Beclomethasone } \\
1,500,2 \text { weeks }\end{array}$ & $\begin{array}{l}\text { Double-blind/"cross-over" } \\
\text { comparison }\end{array}$ & - & $\begin{array}{l}\text { FEV1, FVC and PEFR } \uparrow \text {, but less effective } \\
\text { than prednisone in emphysema }\end{array}$ \\
\hline [16] & 105 & $\begin{array}{l}\text { Beclomethasone } \\
1,500 v s 3,000 \\
3 \text { weeks }\end{array}$ & $\begin{array}{l}\text { Double-blind/"parallel" } \\
\text { comparison }\end{array}$ & - & $\begin{array}{l}\text { FEV1, FVC and PEFR } \uparrow \text {, no difference } \\
\text { between } 1,500 \text { versus } 3,000 \mu \mathrm{g} \text {; PC20 no } \\
\text { change; QOL } \uparrow\end{array}$ \\
\hline [17] & 30 & $\begin{array}{l}\text { Beclomethasone } \\
2,000,6 \text { weeks }\end{array}$ & $\begin{array}{l}\text { Double-blind/"parallel" } \\
\text { comparison }\end{array}$ & - & FEV1, FVC $\uparrow$; inflammation (BAL) $\downarrow$ \\
\hline [18] & 24 & $\begin{array}{l}\text { Budesonide } \\
1,600,8 \text { weeks }\end{array}$ & $\begin{array}{l}\text { Double-blind/"parallel" } \\
\text { comparison }\end{array}$ & 3 & $\begin{array}{l}\text { FEV1, FVC, PEFR, rescue medication } \\
\text { and PC } 20 \text { no change; symptoms (only } \\
\text { dyspnoea) } \downarrow\end{array}$ \\
\hline [19] & 25 & $\begin{array}{l}\text { Budesonide } \\
800,12 \text { weeks }\end{array}$ & $\begin{array}{l}\text { Double-blind/"parallel" } \\
\text { comparison }\end{array}$ & 7 & $\begin{array}{l}\text { FEV } 1, F V \text { and } \mathrm{PC} 20 \text { no change; symptoms } \\
\text { (only cough) } \downarrow\end{array}$ \\
\hline [20] & 14 & $\begin{array}{l}\text { Budesonide } \\
1,200,3 \text { months }\end{array}$ & $\begin{array}{l}\text { Double-blind/"cross-over" } \\
\text { comparison }\end{array}$ & - & $\mathrm{FEV} 1, \mathrm{FVC}$ and $\mathrm{PC} 20$ no change \\
\hline \multicolumn{6}{|c|}{ Long-term studies } \\
\hline$[21,22]$ & 28 & $\begin{array}{l}\text { Beclomethasone } \\
800,12 / 24 \text { months }\end{array}$ & $\begin{array}{l}\text { Single-blind/"within-patient" } \\
\text { comparison }\end{array}$ & 6 & \multirow{2}{*}{$\begin{array}{l}\text { FEV1, FVC and PEFR } \uparrow \text {; PC20 no change; } \\
\text { symptoms, exacerbations (only during } 24 \\
\text { months [22]) and diurnal variation PEFR } \downarrow \\
\text { FEV1, } \uparrow ; \text { exacerbations } \downarrow \text {; PC20 no change }\end{array}$} \\
\hline [23] 39/ & $274^{\dagger}$ & $\begin{array}{l}\text { Beclomethasone } \\
800,30 \text { months }\end{array}$ & $\begin{array}{l}\text { Double-blind/"parallel" } \\
\text { comparison }\end{array}$ & $\begin{array}{l}12 \text { in steroid } \\
\text { group versus } \\
44 \text { in control } \\
\text { group }\end{array}$ & \\
\hline [24] & 58 & $\begin{array}{l}\text { Budesonide } \\
1,600,24 \text { months }\end{array}$ & $\begin{array}{l}\text { Double-blind/"parallel" } \\
\text { comparison }\end{array}$ & $\begin{array}{l}2 / 40 \text { in steroid } \\
\text { versus } 5 / 18 \text { in } \\
\text { control group }\end{array}$ & $\begin{array}{l}\text { Symptoms decreased; FEV } 1 \text { and } \\
\text { exacerbations a nonsignificant improvement }\end{array}$ \\
\hline$[25]^{\#}$ & 194 & $\begin{array}{l}\text { Beclomethasone } \\
1,500,24 \text { months }\end{array}$ & $\begin{array}{l}\text { Double-blind/"parallel" } \\
\text { comparison }\end{array}$ & 24 & $\begin{array}{l}\text { FEV } 1 \text { and PEFR } \uparrow ; \text { less oral steroid days } \\
\text { (during exacerbations) }\end{array}$ \\
\hline
\end{tabular}

: 39 subjects out of 274 had a symptom-based diagnosis of COPD, drop-outs are given for the total group of 274 patients, results only for the 39 COPD patients; \#: published only in abstract form. COPD: chronic obstructive pulmonary disease; [Ref.]: reference number; Pts: patients; FEV1: forced expiratory volume in one second; FVC: forced vital capacity; PEFR: peak expiratory flow rate; PC20: provocative dose of agonist producing a 20\% fall in FEV1; QOL: quality of life; BAL: bronchoalveolar lavage; $\uparrow:$ increased; $\downarrow$ : decreased.

bronchodilator response, $\mathrm{PC} 20$, total immunoglobulin E (IgE) and smoking habits were all independent predictors of the treatment response to inhaled steroids [26]. As already mentioned, a problem in this study was that no distinction was made between asthma and COPD, and the inclusion criteria of this study (increased hyperresponsiveness and reversibility of obstruction) tended to select more asthmatics than patients with COPD. Therefore, on the basis of this study, no firm conclusion can be drawn about predictors of a long-term response to inhaled steroids in COPD. We have, therefore, analysed the data from our study [22], in order to investigate which subgroups of patients with COPD respond most to inhaled corticosteroids [27]. Our hypothesis was that COPD patients with more asthmatic features would benefit most from long-term treatment with inhaled steroids. The improvement in FEV1 during steroid treatment appeared to be greater in patients with more airway obstruction (as assessed by the FEV1/vital capacity (VC)), a higher reversibility of this obstruction, and a larger decline in FEV1 before steroid therapy. Current smokers and smokers with more pack-years showed a worse response to inhaled steroids.

\section{Clinical consequences}

In discussing possible predictors of a long-term response to inhaled steroids, it has to be kept in mind that the studies referred to $[22,23]$ were not set up for this purpose. For instance, in our study [22], which concerned a selective group of patients with COPD, all patients were selected on the basis that they had a decline in lung function of more than $80 \mathrm{~mL} \cdot \mathrm{yr}^{-1}$, which made them less representative of all patients with COPD or asthma. With this limitation in mind, there are indications that in COPD, the bronchodilating response at the start of steroid treatment and the annual decline FEV1 in the preceding period appear to be predictors of the response to the inhaled steroid. Airways that respond only slightly to bronchodilators after a significant decline in lung function may have some degree of damage, such as loss of lung elastic recoil, hypertrophy of airway smooth muscle and thickening of the basement membrane, which may, in some instances, not be reversed either by bronchodilators or by corticosteroids [28, 29]. It is not only in long-term studies that the acute bronchodilating response has been shown to be an important predictor of 
the long-term response to inhaled steroids. In short-term studies with systemic corticosteroids in patients with COPD, a significant relationship was also found between the bronchodilating response and the response to steroids [30-32].

It is possible that patients with the largest increase in airway obstruction during a period when no anti-inflammatory treatment is given, will demonstrate the largest improvements in FEV1 during treatment with the inflammation-reversing corticosteroids. Therefore, in patients with COPD, a large annual decline in FEV1 in the absence of anti-inflammatory treatment is possibly a useful indication for additional treatment with inhaled corticosteroids. It is possible that in these patients smoking plays a less dominant role in the pathogenesis (or progression) of COPD. Current smoking and having a more severe smoking history appeared to be related to the response to inhaled steroids in patients with COPD [22, 23]. This points to the relevance of the amount and duration of smoking to the long-term response to inhaled corticosteroids. More pack-years may be accompanied by more (irreversible) damage to the airways and a lower sensitivity to corticosteroids in COPD. A steroid response in COPD seems to be lowest in subjects with a slow, irreversible deterioration in lung function, probably caused by long and heavy smoking. In patients with a rapidly progressive form of COPD, we hypothesize that treatment with inhaled corticosteroids is probably indicated because of the increased risk of early morbidity and mortality in patients with a low lung function level and a high annual decline in lung function [33, 34]. Large prospective studies in a wide range of patients with COPD are clearly warranted to test this hypothesis. Data from large international studies, such as the Euroscop study, will become available in the near future [35].

It has not yet been proved that COPD patients with typical asthmatic features have a better response to inhaled corticosteroids. Apart from the reversibility, other features of asthma such as a high bronchial hyperresponsiveness and a high diurnal variation of the peak flow did not appear to be the most important determinants of the response to inhaled corticosteroids in COPD [27]. Asthmatic features were predictors of the steroid response in the study of KeRsTJENS et al. [26]. However, this might have been caused by the asthmatic subjects in their mixed study group [23]. Both bronchial hyperresponsiveness (i.e. $\mathrm{PC} 20 \leq 8 \mathrm{mg} \cdot \mathrm{mL}^{-1}$ ) and high diurnal variations of the peak flow (i.e. $>15 \%$ ) are important features of asthma $[3,36]$, which are very much related because they both express bronchial lability of the airways of asthmatics [36]. The degree of nonspecific bronchial responsiveness is closely related to the severity of inflammation in asthma [3]. Therefore, it seems logical that asthmatic subjects with severe bronchial hyperresponsiveness demonstrate the largest responses to inhaled corticosteroids.

It is possible that bronchial hyperresponsiveness in asthma is not the same as in COPD. JAMES et al. [37] found no relationship between $\mathrm{PC} 20$ and response to corticosteroids in patients with COPD. It is possible that bronchial hyperresponsiveness in COPD does not signify inflammation as it does in asthma, but is rather an expression of the degree of existing airway obstruction $[38$,
39]. In none of the COPD studies could any influence of inhaled steroids on bronchial hyperresponsiveness (assessed by means of PC20) be observed [11-25]; whilst in all of the asthma studies, a significant reduction of bronchial hyperresponsiveness was shown [5-7, 21-23]. It seems probable that the inflammation in COPD is less responsive to inhaled corticosteroids than it is in asthma. This might be caused by the high steroid sensitivity of lymphocytes and eosinophils, which are found in relatively high numbers in asthma but to a lesser extent in COPD in BAL studies [40].

In conclusion, use of inhaled steroids in chronic obstructive pulmonary disease seems to have some (in part dose-dependent) beneficial effects on lung function but not on bronchial hyperresponsiveness. Inhaled corticosteroids in chronic obstructive pulmonary disease may have some small effects on bronchial symptoms and exacerbations. There are indications that more reversibility of the airway obstruction and less smoking might be related to a better long-term response to inhaled steroids in chronic obstructive pulmonary disease. However, before translating this to clinical practice, more data are urgently needed to support these observations. Long-term data with inhaled steroids in chronic obstructive pulmonary disease will soon become available.

\section{References}

1. Barnes PJ. Drug therapy: a new approach to the treatment of asthma. N Engl J Med 1989; 321(22): 1517-1527.

2. National Heart, Lung, and Blood Institute, National Institutes of Health. International consensus report on diagnosis and treatment of asthma. Eur Respir J 1992; 5: 601-641.

3. Djukanovic R, Roche WR, et al. Mucosal inflammation in asthma. Am Rev Respir Dis 1990; 142: 434-447.

4. Corrigan CJ, Kay AB. The roles of inflammatory cells in the pathogenesis of asthma and of chronic airflow limitation. Am Rev Respir Dis 1991; 143: s1165-s1168.

5. Haahtela T, Järvinen M, Kava T, et al. Comparison of a beta ${ }_{2}$-agonist, terbutaline, with an inhaled corticosteroid, budesonide, in newly detected asthma. N Engl J Med 1991; 325: 388-392.

6. Juniper EF, Kline PA, Vanzieleghem MA, Ramsdale EH, O'Byrne PM, Hargreave FE. Effect of long-term treatment with an inhaled corticosteroid (budesonide) on airway hyperresponsiveness and clinical asthma in non-steroiddependent asthmatics. Am Rev Respir Dis 1990; 142: 832-836.

7. Juniper EF, Kline PA, Vanzieleghem MA, Ramsdale EH, O'Byrne PM, Hargreave FE. Long-term effects of budesonide on airway responsiveness and clinical asthma severity in inhaled steroid-dependent asthmatics. Eur Respir J 1990; 3: 1122-1127.

8. Postma DS. Inhaled therapy in COPD: what are the benefits? Respir Med 1991; 85: 447-449.

9. Wedzicha JA. Inhaled corticosteroids in COPD: awaiting controlled trials. Thorax 1993; 48: 305-307.

10. Postma DS, Sluiter HJ. Prognosis of chronic obstructive pulmonary disease: the Dutch experience. Am Rev Respir Dis 1989; 140: s100-s105.

11. Shim CS, Williams MH. Aerosol beclomethasone in patients with steroid-responsive chronic obstructive pulmonary disease. Am J Med 1985; 78: 655-658.

12. Robertson AS, Grove WI, Wieland GA, Burge PS. A 
double-blind comparison of oral prednisolone $40 \mathrm{mg} \cdot$ day $^{-1}$ with inhaled beclomethasone dipropionate $1,500 \mu \mathrm{g} \cdot \mathrm{day}^{-1}$ in patients with adult onset chronic obstructive airways disease. Eur J Respir Dis 1986; 146 (Suppl.): 565-569.

13. Weir DC, Gove RI, Robertson AS, Burge PS. Corticosteroid trials in non-asthmatic chronic airflow obstruction: a comparison of oral prednisolone and inhaled beclomethasone dipropionate. Thorax 1990; 45: 112-117.

14. Weir DC, Robertson AS, Gove RI, Burge PS. Time course of response to oral and inhaled corticosteroids in non-asthmatic chronic airflow obstruction. Thorax 1990; 45: 118-121.

15. Weir DC, Gove RI, Robertson AS, Burge PS. Response to corticosteroids in chronic airflow obstruction: relationship to emphysema and airways collapse. Eur Respir J 1991; 4: 1185-1190.

16. Weir DC, Burge PS. Effects of high-dose inhaled beclomethasone dipropionate, $750 \mu \mathrm{g}$ and $1,500 \mu \mathrm{g}$ twice daily, and $40 \mathrm{mg}$ per day oral prednisolone on lung function, symptoms, and bronchial hyperresponsiveness in patients with non-asthmatic chronic airflow obstruction. Thorax 1993; 48: 309-316.

17. Thompson AB, Mueller MB, Heires AJ, et al. Aerosolized beclomethasone in chronic bronchitis: improved pulmonary function and diminished airway inflammation. $A m$ Rev Respir Dis 1992; 146: 389-395.

18. Auffarth B, Postma DS, de Monchy JG, van der Mark TW, Boorsma M, Koeter GH. Effects of inhaled budesonide on spirometric values, reversibility, airway responsiveness, and cough threshold in smokers with chronic obstructive lung disease. Thorax 1991; 46(48): 372-377.

19. Engel T, Heinig JH, Madsen O, Hansen M, Weeke ER. A trial of inhaled budesonide on airway responsiveness in smokers with chronic bronchitis. Eur Respir J 1989; 2: 935-939.

20. Watson A, Lim TK, Joyce H, Pride NB. Failure of inhaled corticosteroids to modify bronchoconstrictor or bronchodilator responsiveness in middle-aged smokers with mild airflow obstruction. Chest 1992; 101: 350-355.

21. Dompeling E, van Schayck CP, Molema J, Folgering H, van Grunsven PM, van Weel C. Inhaled beclomethasone improves the course of asthma and COPD. Eur Respir J 1992; 5: 945-952.

22. Dompeling E, van Schayck CP, van Grunsven PM, et al. Slowing the deterioration of asthma and chronic obstructive pulmonary disease observed during bronchodilator therapy by adding inhaled corticosteroids. Ann Intern Med 1993; 118: 770-778.

23. Kerstjens HAM, Brand PLP, Hughes MD, et al. A comparison of bronchodilator therapy with or without inhaled corticosteroid therapy for obstructive airways disease. $N$ Engl J Med 1992; 327: 1413-1419.

24. Renkema TEJ, Schouten JP, Koeter GH, Postma DS. Effects of long-term treatment with corticosteroids in COPD. Chest 1996; 109: 1156-1162.

25. Derenne JPh. Effects of high-dose inhaled beclomethasone on the rate of decline in FEV1 in patients with chronic obstructive pulmonary disease: results of a 2 years prospective multicentre study (Abstract). Am J Respir Crit Care Med 1995; 151: A463.

26. Kerstjens HAM, Overbeek SE, Schouten JP, Brand PLP, Postma DS and the Dutch CNSLD Study Group. Airways hyperresponsiveness, bronchodilator response, serum $\mathrm{IgE}$, and smoking habit predict improvement in FEV1 during long-term inhaled corticosteroid treatment. Eur Respir J 1993; 6: 868-876.

27. van Schayck CP, Dompeling E, Molema J, van Grunsven PM, Folgering H, van Weel C. Which COPD patients benefit most from long-term inhaled corticosteroids (Abstract)? Am J Respir Crit Care Med 1995; 151(4): A467.

28. Freedman BJ. Patterns of response to bronchodilators in asthma. Br J Dis Chest 1978; 72: 95-107.

29. Brown PJ, Greville HW, Finucane KE. Asthma and irreversible airflow obstruction. Thorax 1984; 39: 131-136.

30. Mendella LA, Manfreda J, Warren CPW, Anthonissen NR. Steroid response in stable chronic obstructive pulmonary disease. Ann Intern Med 1982; 96: 17-21.

31. Stokes TC, Shaylor JM, O'Reilly JF, Harrison BDW. Assessment of steroid responsiveness in patients with chronic airflow obstruction. Lancet 1982; ii: 345-348.

32. Blair GP, Light RW. Treatment of chronic obstructive pulmonary disease with corticosteroids: comparsion of daily vs alternate day therapy. Chest 1984; 86: 524-528.

33. Postma DS, Burema J, Gimeno F, et al. Prognosis in severe chronic obstructive pulmonary disease. Am Rev Respir Dis 1979; 119: 357-367.

34. Burrows B, Bloom JW, Traver GA, Cline MG. The course and prognosis of different forms of chronic airways obstruction in a sample from the general population. N Engl J Med 1987; 317: 1309-1314.

35. Pauwels R, Lofdahl CG, Pride NB, Postma DS, Laitinen LA, Ohlsson SV. European Respiratory Society study on chronic obstructive pulmonary disease (EUROSCOP): hypothesis and design. Eur Respir J 1992; 5: 1254-1261.

36. Hargreave FE, Ryan G, Thomson NC, et al. Bronchial responsiveness to histamine and methacholine: measurement and clinical significance. J Allergy Clin Immunol 1981; 68: 347-355.

37. James AL, Finucane KE, Ryan G, Musk AW. Bronchial responsiveness, lung mechanics, gas transfer, and corticosteroid response in patients with chronic airflow obstruction. Thorax 1988; 43: 916-922.

38. Pride NB, Taylor RG, Lim TK, Joyce H, Watson A. Bronchial hyperresponsiveness as a risk factor for progressive airflow obstruction in smokers. Bull Eur Physiopathol Respir 1987; 23: 369-375.

39. van Schayck CP, Dompeling E, Molema J, Folgering H, van Grunsven PM, van Weel C. Does bronchial hyperresponsiveness precede or follow airway obstruction in asthma or COPD? Neth J Med 1994; 45: 145-153.

40. Robinson DS. The immunopathology of asthma and chronic obstructive pulmonary disease. In: Postma DS, Gerritsen J, eds. Bronchitis. V. Proceedings of the fifth international symposium on advances in understanding of asthma and COPD. The Netherlands, Van Gorcum, Assen, 1994; pp. 40-52. 